\title{
Ecoliteracy of Elementary School Students in Social Studies: In Online Learning During the Pandemic of COVID 19
}

\author{
Nuni Ruqiyyatus Sholihah ${ }^{1 *}$ Sapriya $^{1}$ Nana Supriatna ${ }^{1}$ Kokom Komalasari ${ }^{1}$

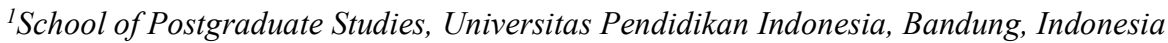 \\ *Corresponding author.Email:nuniruqiyyatussholihah@email.com
}

\begin{abstract}
Learning during the Covid 19 pandemic is closely related to online learning and School from Home. Achievement of learning outcomes during this pandemic is no longer focused on material attainment but rather on cultivating the character of students. This study aims to describe the application of ecoliteracy learning in social studies learning during the Covid 19 pandemic by using the concept of zero waste for sustainable development in primary schools. The design of this research is a descriptive qualitative research. Data collection was carried out through observation and documentation and analyzed qualitatively. The results of this study indicate that (1) ecoliteracy learning in social studies learning using the concept of zero waste carried out online through home learning can increase students' care and love for nature and the environment as early as possible. (2) establishing a more harmonious relationship between students and family members. Character planting through social studies learning during the Covid 19 pandemic can run smoothly with good cooperation between teachers and parents.
\end{abstract}

Keywords: Ecoliteracy, social studies, zero waste, learning during the pandemic of Covid 19.

\section{INTRODUCTION}

Increasing students' environmental care attitude is very important to be developed from an early age. Students are said to have had an attitude if they had taken the same action in the same situation. This happens repeatedly [1]. Habitual values of positive attitude character values will not easily fade so that along with age development, students will become accustomed to always care about their surroundings both in the school, home, and community environment.

Environmental problems, especially in the school environment that occurred before the Covid 19 pandemic, such as the huge volume of waste due to snacks served using plastic packaging, sterofoam etc. Due to the number of trash bins that cannot accommodate the resulting trash, the garbage is scattered so that the school environment becomes dirty. This can be seen from the attitude of students' indifference to the school environment which is shown by the behavior of the many students littering, indifference to plants so that there is a lot of garbage in the pots which results in wilted and dry plants. Students are reluctant to bring drinking and eating places from home for reasons that are impractical and not slang, as stated by [2] that the mechanism of the consumption system basically departs from the value-symbol system, and not because of need or desire gets pleasure. This event is a problem caused by students who reflect their indifference to the environment. Environmental problems that occur illustrate the lack of awareness of the importance of the environment. This awareness is what [3] calls ecoliteracy.
A person's ecological intelligence is based on knowledge, attitudes / awareness, and actions / behavior in harmony with the natural environment. As explained by Supriatna [4] that ecological intelligence is complex. This intelligence is supported by cognitive, affective (social and emotional), and psychomotor elements. The desire to protect the environment is based on knowledge of the environment. Awareness to save a damaged environment is based on affective aspects, while actions to conserve the environment describe psychomotor aspects.

To foster student ecoliteracy, teachers are one of the keys to helping improve ecoliteracy through habituation and role models as well as dialogue which will grow and develop into an awareness of each individual. as stated by Paulo Freire (p. 77) that the importance of dialogue in the education of the oppressed. "If in speaking his own words humans can change the world by naming it, then dialogue asserts itself as a means by which a person acquires meaning as a human being. Contextual learning-based learning in which there is a dialogue between teachers and students will create meaningful learning, students will be served in fulfilling their enormous curiosity as conveyed by Supriatna that existential principles in the development of the social studies curriculum place social studies material contextually according to the situation and local conditions that allow student experiences to be appointed as learning material as well as making him an actor to solve social problems faced in everyday life in the local environment. This will be very important in line with the development of science and technology. Without environmental awareness, 
science and technology will actually affect the inequality of nature. Thus, there must be concrete actions to develop student ecoliteracy.

Departing from small things in school, teachers still have to teach and foster an understanding of this environment through social studies learning, including social studies learning during the Covid 19 pandemic. The Covid 19 pandemic has changed various aspects of human life today, especially in the world of education, including the level primary school. The story of this outbreak can have a different ending for each country [5] depending on the policies implemented and the responsiveness of the government to minimize its spread. Therefore, since March 2020 the government through the ministry of education and culture issued a circular to implement a policy of moving face-to-face classrooms to online classrooms known as the School from Home program (Regulation of Indonesian Government No.21, 2020). The government policy issued to limit the spread of COVID-19 has an impact on various fields around the world, especially education in Indonesia. Learning during the COVID-19 pandemic is synonymous with online learning and School from Home. Given that during the pandemic, time, location and distance are major problems today [6] the distance learning policy using online learning is one of the best solutions to overcome difficulties in implementing face-to-face learning. Online learning has occurred almost worldwide during the COVID-19 pandemic [7]. Learning during the pandemic in Indonesia is called Learning from Home which is carried out in accordance with the principles contained in the Circular of the Minister of Education and Culture of the Republic of Indonesia Number 4 of 2020 concerning Implementation of Education Policies in an Emergency the Spread of Corona Virus Disease (Covid 19), including learning activities from home implemented to provide meaningful learning experiences for students (without being burdened with demands to complete all curriculum achievements); and can be focused on life skills education.

Life skills education that can be developed in social studies learning during Learning from Home, namely the application of ecoliteracy development during the Covid-19 pandemic in dealing with waste problems in the school environment switching to the home environment can be integrated with the concept of zero waste. Zero Waste International Alliance [8] says that zero waste as "designing and managing products and processes systematically to eliminate the waste and materials, conserve and recover all resources and not burn or bury them. The application of the concept of zero waste reduce, re-use, replace and recycle in the development of student ecoliteracy in social studies learning is expected to foster student awareness in protecting the environment, starting from the environment closest to students, namely the home environment.

Based on the background that I presented above, this paper intends to explore, discover and integrate the concept of Zero Waste in social studies learning in improving the ecoliteracy of elementary school students during the Covid 19 pandemic by way of waste management carried out directly by each student so as to form a concern for the surrounding environment at the same time can increase social awareness which affects the character building. The formulation of the problem posed in this paper is how the process of improving the ecoliteracy of elementary school students based on the concept of zero waste in social studies learning.

\subsection{Ecoliteracy}

According to [9] Ecoliteracy is the ability to understand natural systems that support the sustainability of life on earth or the sustainability of life. Ecoliteracy is a process of increasing understanding, knowledge, attitudes and behavior based on ecology. Ecoliteracy seeks to introduce and renew one's understanding of realizing global ecological awareness, in order to create a balance between the needs of society and the ability of the earth to sustain it. According to [10] ecoliteracy is a way of thinking about global environmental awareness which is useful for creating a balance between the needs of society and the abilities of nature, including in considering the consequences of human action and interactions in a natural context. Furthermore, Capra explained the aspects of ecoliteracy, namely the principles of living systems, design inspired by nature, systems of thought, ecological paradigms and transitions for sustainability, collaboration, and building community and citizenship. [11] states that:

The great challange of our time is to build and nurture sustainable communities-communities that are designed in such a way that their ways of life, businesses, economies, physical structures, and technologies do not interfere with nature's inherent ability to sustain life. The first step in this endeavor is to understand the principles of organization that ecosystems have developed to sustain the web af life. This understanding is what we call ecological literacy.

From the quote above, it can be argued that the big challenge today is building and maintaining a sustainable society. Society is designed in such a way that the way of life, business, economy, physical structure and technology do not interfere with nature's ability to sustain life. The first step in this effort is to understand the organizational principles of the ecosystem as the web of life. This understanding is what we call ecological literacy. Ecologically literate people not only and respect the natural environment, but also respect life itself [12]. The emergence of a paradigm about ecoliteracy is to create public understanding of the importance of global ecological awareness, so that there is a balance between community needs and environmental strength limits [13]. Through education in schools with environmental care movements that are applied to students to build Ecoliteracy. Currently education related to sustainability and nature preservation is needed. The school's function as the inheritor of the nation's values and culture must be carried out by the school. So, every learning in school should be integrated with the activities of Ecology Literacy through environmental care movements. 


\subsection{Social studies}

We can do the operationalization of the concept of ecoliteracy or environmental education in social studies education by constructing a network / linkage between a set of core competences that are standardized with Core Competencies and basic competencies contained in the 2013 curriculum and indicators of their achievement. The Center for Ecoliteracy (http: //www.ecoli eracy.org/d iscover / competing cies), for example, has developed a standard or core competency structure (a set of core competence) ecoliteracy that can be developed in learning. This competency is related to the cognitive domains (learning to know), affective (learning to be), psychomotor (learning to do), and relationships with humans and the natural environment (learning to live together). An example of a set of core competences from the center for ecoliteracy can be used as a reference in developing ecoliteracy of students through social studies learning in elementary schools through competencies that students must achieve, namely. Analyze the forms of human interaction with the environment and their effects on the social, cultural and economic development of Indonesian society.

\subsection{Zero Waste Concept}

Zero waste is basically a principle or philosophy to design the cycle of a resource so that it allows all of them to be used by minimizing waste productivity. According to other sources, zero waste includes processes to maximize recycling, minimize waste, streamline consumption and ensure a product can be used. returned, or at least recycled so that it can be reduced by nature. This is a very visionary goal by prioritizing efficiency, economics and an ethical attitude towards nature. This principle can also basically guide people in changing their lifestyles and practices to mimic nature's sustainable cycles, where all materials that have been discarded, are designed to be a resource for others to use.

But the concept of zero waste or zero emission in a literal sense is impossible to realize. Because in general all processes will produce residual substances. So that the most expected from this principle is that the resulting waste or emissions can be reduced easily and quickly. Zero waste includes all human activities. So that all areas of life and all human activities can apply this principle. For example, in the field of natural resources, production emissions, human activities such as those related to administration and production, transportation, especially those related to waste. The expected benefits from the concept of zero waste are being able to support economic sustainability, environmental carrying capacity and social carrying capacity.

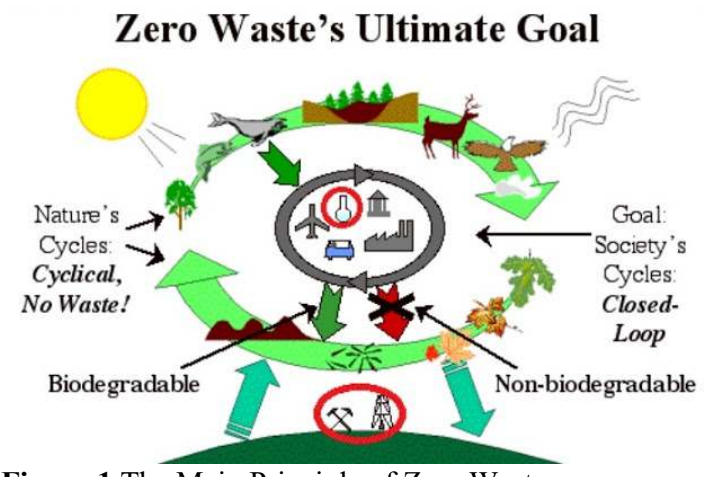

Figure 1 The Main Principle of Zero Waste

The concept of zero waste is one of them by applying the 3R principle (Reduce, Reuse, Recycle). The concept of zero waste is an integrated approach and application of municipal waste processing systems and technologies on an individual and regional scale with the aim of reducing the volume of waste as little as possible. The approach and application of waste processing systems and technology in this $3 R$ activity into $4 R$ is added to the Replace activity. The $4 \mathrm{R}$ concept is the basis for various efforts to reduce waste and optimize the waste production process. From the $4 \mathrm{R}$ principle, the methods that are considered quite effective in reducing the impact of plastic waste are the reuse and recycle methods. Reuse, namely creating and innovating to make plastic waste into useful items such as handicrafts that are worth selling. Meanwhile, recycling is the process of preparing plastic waste into raw materials to be reprocessed into new industrial scale products [14].

\section{METHOD}

Online learning is a set of government policies through the ministry of education and culture to address the prevention of COVID-19. This online learning model attempts to break the chain of COVID-19 by implementing social distancing and distance learning or learning from home using the internet network. This research is a qualitative descriptive study. The data used in this study were obtained through observation, questionnaires sent via Google form, online interviews via social media, and documentation. Observations are made based on the face-to-face learning policy of switching to an online learning system; The questionnaire was carried out to determine the students' learning system which was run online due to the spread of COVID-19. Interviews were conducted with selected informants based on constructive responses and opinions related to the application of social studies learning during the Covid pandemic in order to increase student ecoliteracy. The data obtained through a questionnaire was carried out by distributing a questionnaire in the form of Google form application and distributed through social media networks containing questions that included learning conditions during the pandemic, current environmental conditions and problems, solutions to problems that arise, students' responses when practicing, the concept of zero waste in social studies learning when learning from home. The 
questionnaire was distributed randomly to 6th grade students at SDN Kresna. From the distribution of incoming questionnaires, there were 38 respondents. Interviews were conducted to find out more in-depth information regarding the process of implementing the zero waste concept in social studies learning through ongoing online learning. There were 5 informants who were interviewed. Question content about the application of ecoliteracy learning using the concept of zero waste in social studies learning models with online learning models during the COVID 19 pandemic. At the same time, this study uses product documentation techniques and photos or videos of students' activities during distance learning or Learning from Home. The data were analyzed through the processes of 1) data regrouping by their respective themes, 2) description carried out to find patterns and data trends, and 3) interpretations aimed at understanding the meaning of the informants' statements. The reduced data is then thematically displayed in the pictorial form and interview excerpts. In the final stage, data verification is carried out to give birth to a deep and comprehensive understanding of the data.

\section{RESULT AND DISCUSSION}

Based on the recapitulation of the questionnaire responses, it was obtained the following percentage data:
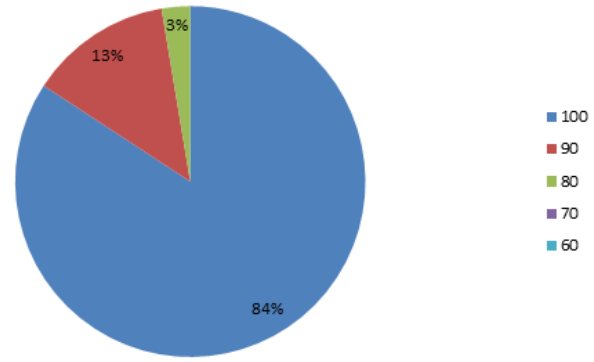

Figure 2 Percentage of students' knowledge about waste management

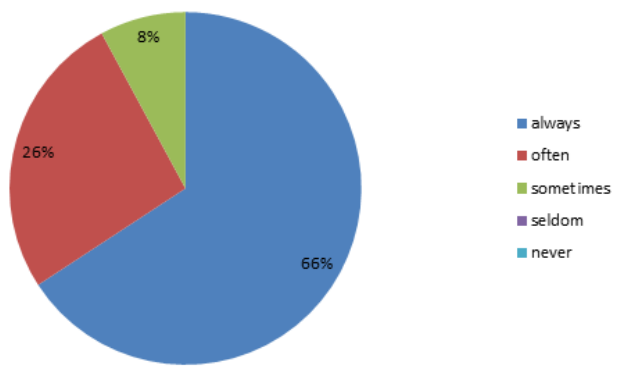

Figure 3 The percentage of student activities in disposing of trash in its place

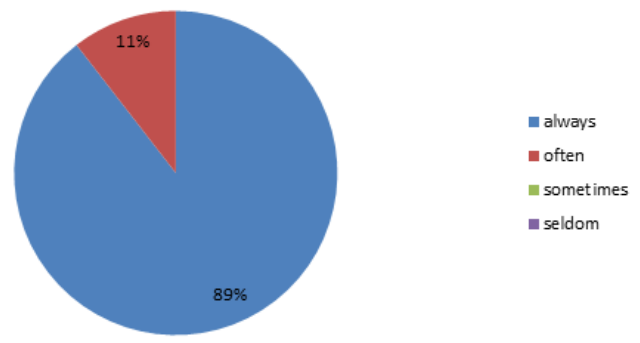

Figure 4 The percentage of student activities in recycling waste "Recycle"

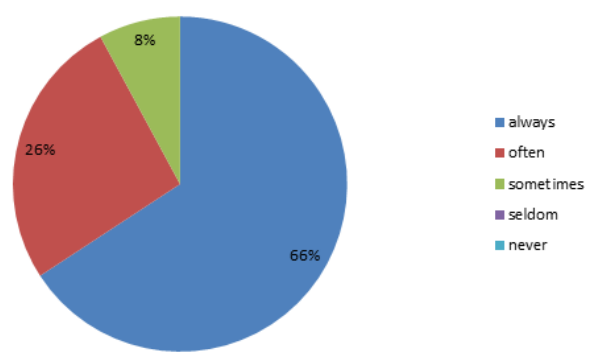

Figure 5 The percentage of student activities in reducing waste by reducing the use of objects that produce garbage "Reduce"

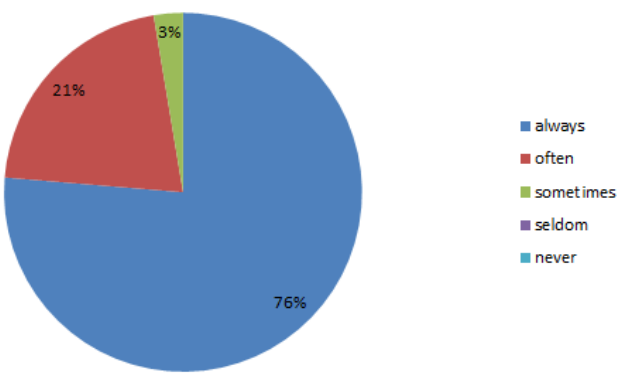

Figure 6 Percentage of student activity in reusing objects that can still be used "Reuse"

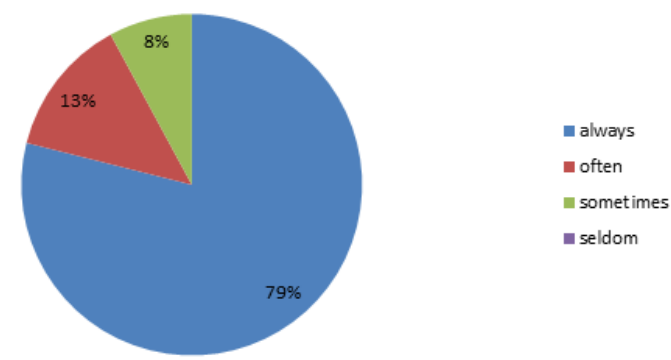

Figure 7 The percentage of student activities in replacing old items with items that are more environmentally friendly "Replace". 
Based on the data obtained, it was estimated that after students get social studies learning online in improving student ecoliteracy based on the zero waste program through 4R (Reduce, Reuse, Recycle, and Replace), students can apply the program in their daily activities with their families. As discussed in Diagrams 3,4,5, and 6, students always try to do the program of zero waste. Based on these data, it shows that the zero waste program carried out has described ecoliteracy in students. The achievement of student ecoliteracy can be identified by three indicators, namely knowledge, awareness and application.

Based on the results of the analysis that has been carried out on 38 class VI-A respondents at 015 Kresna elementary school, it shows that the level of knowledge of respondents about the form of human interaction with the environment through the application of a zero waste program with the aim of human survival in the very good category tends to be more than the respondents who have knowledge is categorized as good and sufficient, this can be seen in diagram 1 above, 32 respondents $(84 \%)$ who get a value of ' 100 ' mean that the level of knowledge is very good, and those who get a value of ' 90 ' are 5 respondents $(13 \%)$ means that the level of knowledge is good about the form of human interaction with the environment and its impact on the sustainability of the social, cultural and economic development of the Indonesian people through the implementation of the Zero Waste program.

Students have been able to explain and understand well that one form of good human interaction with the environment is through the implementation of the Zero Waste program or waste free program. as has been explained that waste is part of something that is not used, disliked or something that must be disposed of, which generally comes from activities carried out by humans (including industrial activities), but not biological (because human waste is not included in it) and generally solid. In general, the definition of waste is goods or objects that are discarded because they are not used or used by their owners.

\subsection{Ecoliteracy based on the concept of Zero Waste in Social Studies Learning during the pandemic of Covid 19}

One of the results of the Earth Summit from the activities of the United Nations Conference on Environment and Development (UNCED) in Rio de Jenerio 3-4 June 1992 is a recommendation for the implementation of sustainable development (sustainable development) in the 21 st century through the implementation of education that is integrated with environmental problems or environmental based education. This is in line with the opinion of Palmer (2003).

one of the key outcomes of conference for educators is therecommendation that environmental and development education should be incorporated as an essential part of learning, within both formal and non-formal education sector.
Education is significant in changing a person's mindset and way of behaving. Through education someone will become smart and good. Including one's ecological awareness can be grown through an educational process that teaches a person to protect and care for the environment through various environmentally friendly behaviors and care for the environment through various environmentally friendly behaviors that will contribute to the formation of a sustainable society.

UNESCO (1975) in Palmer (2003, p.13) also formulates the objectives of environmental education, namely: (1) To generate clear awareness and concern about economics, political and ecological interdependence in urban and rural areas; (2) To give everyone the opportunity to acquire knowledge, values, attitudes, commitments and skills necessary to protect and improve the environment; (3) To create new patterns of behavior of individuals, groups and society as a whole towards the environment.

In line with this, social studies learning teaches students to develop tolerant, empathetic, responsible attitudes in exercising rights and obligations related to interactions with the environment around students. In order to accommodate the development of these values, it is necessary for teachers to creatively pour them into the atmosphere and learning activities, especially during the Covid 19 pandemic. In this effort the teacher has a big share in providing understanding to students of the importance of environmental awareness. In fact, students are expected to form a good personality and this will be reflected in every behavior in their daily life. This is done by involving students to participate in maintaining a healthy and clean home and surrounding environment so as to create an atmosphere that makes it comfortable for all people in the home and surrounding environment.

Zero waste-based social studies learning activities as described above can be used as fun learning for students because they can be directly involved in preserving the local environment through $4 \mathrm{R}$ activities. This aims to make students more concerned about problems that occur in the environment closest to students. This can affect attitudes and behaviors that are always concerned with social conditions that can harm many people. The role of students in actively protecting the environment closest to students can have a positive impact on the creation of a clean and healthy environment. Therefore, good habits like this can bring out a social concern that is embedded in student behavior.

Zero waste-based social studies learning in order to improve student ecoliteracy, especially in this pandemic, requires teacher creativity in implementing distance learning social studies through online learning. Teachers and educators as essential elements in teaching are required to undertake an unprecedented massive migration from traditional face-toface education to online education or distance education [15]. Online learning is defined as a knowledge transfer experience using video, audio, images, text communication, software and with internet network support [16]. Online learning demands the role of the educator to evaluate the effectiveness and adapt it to learning needs. It is important 
to do this to fulfill aspects of learning such as the process of knowledge, morals, skills, intelligence and aesthetics [17] [18].

Online learning during this pandemic can take advantage of the facilities. Infrastructure that supports free online learning through various discussion rooms such as Google Classroom, Whatsapp, Smart Class, Zenius, Quipper and Microsoft [19]. Another obstacle that was found was the ability of parents to provide online education facilities such as the use of internet networks that require money [20]. The key is to conduct online learning according to local conditions [21]. The most important thing is to create independence and learning skills for students in the midst of the COVID-19 pandemic.

\section{CONCLUSION}

The increase in ecoliteracy based on the concept of zero waste in social studies learning which is carried out directly by each student is a form of concern for the surrounding environment as well as to increase social awareness that affects character building. Distance learning during a pandemic is not an obstacle in increasing the ecoliteracy of students in social studies learning based on zero waste. Based on the results of the analysis that ecoliteracy learning in social studies learning using the concept of zero waste carried out online through home learning can increase students' care and love for nature and the environment as early as possible. Learning during the Covid pandemic 19 Teachers and parents play a role in increasing student ecoliteracy. Character planting through social studies learning during the Covid 19 pandemic can run smoothly with good cooperation between teachers and parents and establishing a more harmonious relationship between students and family members.

\section{REFERENCE}

[1] Karlina dkk. 2017. Ecoliteracy Siswa Sd Dalam Kegiatan Pengelolaan Sampah Melalui Group Investigation Berbasis Outdoor Study. Jurnal Pendidikan, Vol. 2, No. 7, Bln Juli, Thn 2017, Hal 991-1002

[2] Baudrillard, J. 1998. The Consumer Society Myths and Structures. SAGE Publication. London. Thousand Oaks, New Delhi

[3] Capra, F. 2002. Jaring-Jaring Kehidupan. Yogyakarta: Fajar Pustaka Baru

[4] Supriatna, N. (2016). Ecopedagogy Membangun Kecerdasan Ekologis dalam Pembelajaran IPS. Bandung: Remaja Rosdakarya

[5] Lee, A. (2020). Wuhan novel coronavirus (COVID-19): why global control is Jurnal Teknologi Pendidikan Vol. 22, No. 1, April 2020 70 challenging? Public Health, January, 19- 21.

[6] Kusuma, J. W., \& Hamidah. (2020). Platform Whatsapp Group Dan Webinar Zoom Dalam Pembelajaran Jarak Jauh Pada Masa Pandemik
Covid 19. Jurnal Ilmiah Pendidikan Matematika Volume, 5(1)

[7] Goldschmidt, K., \& Msn, P. D. (2020). The COVID-19 pandemic: Technology use to support the wellbeing of children. Journal of Pediatric Nursing, xxxx, 3-5.

[8] Zaman. 2017. A Strategic Framework for Working toward Zero Waste Societies Based on Perceptions Surveys doi:10.3390/recycling2010001

[9] Supriatna, N. (2016). Ecopedagogy Membangun Kecerdasan Ekologis dalam Pembelajaran IPS. Bandung: Remaja Rosdakarya

[10] Capra, F. 2011. Ecological Literacy. Journal of Draft Global Issues Pilot August. (1-15)

[11] Capra, F. (1995). The Web of Life, Harper Collins. Tersedia Online di http://www.ecoliteracy.org/publica tions/frijop (diakses tanggal 17 Agustus 2020)

[12] Rondli dkk. 2017. Pembelajaran Pendidikan Kewarganegaraan Berbasis Ecoliteracy: Upaya Rekontruksi Kewarganegaraan Ekologis. Prosiding Seminar Nasional. Program Studi Pendidikan Guru Sekolah Dasar Universitas Muria Kudus

[13] Sartika dkk. 2014. Pengaruh Word of Mouth dan Ecoliteracy Terhadap Green Purchasing (Survei pada Mahasiswa Fakultas Ilmu Administrasi Prodi Administrasi Universitas Brawijaya Malang Angkatan 2010/2011 dan 2011/2012 Pengguna Produk Tupperware). Jurnal Administrasi Bisnis (JAB)| Vol. 17 No. 2 Desember 2014

[14] Lisdiana dkk. 2016. Pengelolaan Sampah Plastik Di Lingkungan Sekolah Adiwiyata. Seminar Nasional Inovasi IPTEKS Perguruan Tinggi untuk Meningkatkan Kesejahteraan Masyarakat. Denpasar- Provinsi Bali

[15] Bao, W. (2020). COVID-19 and online teaching in higher education: A case study of Peking University. March, 113-115. https://doi.org/10.1002/hbe2.191

[16] Zhu, X., \& Liu, J. (2020). Education in and After Covid-19: Immediate Responses and LongTerm Visions

[17] Dai, D., \& Lin, G. (2020). Online Home Study Plan for Postponed 2020 Spring Semester during the COVID-19 Epidemic: A Case Study of Tangquan Middle School in Nanjing, Jiangsu Province, China. SSRN Electronic Journal. https://doi.org/10.2139/ssrn.3555539

[18] Zhu, X., \& Liu, J. (2020). Education in and After Covid-19: Immediate Responses and LongTerm Visions

[19] Abidah, A., Hidaayatullaah, H. N., Simamora, R. M., Fehabutar, D., \& Mutakinati, L. (2020). The Impact of Covid-19 to Indonesian Education and Its 
Relation to the Philosophy of "Merdeka Belajar." Studies in Philosophy of Science and Education, $1(1), 38-49$.

[20] Jones, K., \& Sharma, R. (2019). REIMAGINING A FUTURE FOR ONLINE LEARNING
[21] Zhang, W., Wang, Y., Yang, L., \& Wang, C. (2020). Suspending Classes Without Stopping Learning: China's Education Emergency Management Policy in the COVID-19 Outbreak. Risk and Financial Management, 13(55), 1-6 